\title{
Introduction
}

\author{
Marco Faini and Alessia Meneghin
}

In recent decades, a wealth of publications has examined the role of religion in early modern society, culture and politics. This includes pioneering work on the importance of lay piety to civic identity in the Renaissance period. ${ }^{1}$ Many more studies have focused on the upheavals associated with the Protestant and Catholic Reformations, and in the last thirty years historians of Protestant Europe have expanded their focus to include the family and the home within studies of religious change. ${ }^{2}$ However, the focus on the intimate and meditative nature of Lutheranism, Calvinism and Anglicanism, has tended to distract historians from gaining a proper understanding of those cultural formations that were simultaneously also present in Catholic homes. The same historiographical tradition, emerging from Reformation studies, has been even slower to forge comparisons with regions outside Europe and faiths beyond Christianity. Given the vast array of religious beliefs and practices throughout the early modern world and bearing in mind their distinct patterns of historical evolution, it is evident that a one-size-fits-all model of comparison will not serve to explain what domestic - or private - piety is. We are equally conscious that the use of a European periodization in a global perspective is not unproblematic. However, we are emboldened by the fact that historians of East Asia have recognized the value of adopting terms and appropriating concepts from the western historiographical tradition. For example, Craig Clunas has experimented with the idea of a Burckhardtian Renaissance in relation to Ming China, while Kai-Wing Chow argues forcibly for the relevance of 'early modern' in his study of print culture in China. ${ }^{3}$

1 See the seminal work of Trexler R.C., Public Life in Renaissance Florence (Ithaca, NY: 1991).

2 Forster M.R. - Kaplan B.J. (eds.), Piety and Family in Early Modern Europe: Essays in Honour of Steven Ozment (London: 2005); Doran J. - Methuen C. - Walsham A. (eds.), Religion and the Household (Woodbridge, Suffolk - Rochester, NY: 2014).

3 In his Empire of Great Brightness: Visual and Material Culture of Ming China, 1368-1644 (London: 2008) 7-20, Craig Clunas uses the argument of 'taste' - as expressed by Jacob Burckhardt in his analysis of Renaissance civilization - about Ming Dynasty China, suggesting a parallelism to early modern Europe, seeing both eras as witnessing 'the invention of taste'. For example in the case of tea culture, a highly sophisticated sense of good taste came long before the Ming; on this see Clunas C., Superfluous Things: Material Culture and Social Status in Early Modern China (Cambridge: 1991) 171. In a similar vein, Kai-Wing Chow's book, Publishing, Culture and Power in Early Modern China (Redwood City, CA: 2004), invites the reader to refrain from concentrating exclusively on the crucial role that the press held

(C) MARCO FAINI AND ALESSIA MENEGHIN, 2019 | DOI:10.1163/9789004375888_002

This is an open access chapter distributed under the terms of the prevailing CC-BY-NC-ND License at the time of publication. 
This volume examines domestic devotions from a global perspective from 1400 to 1800 , focusing on a range of faiths and places around the world. We think that a global outlook on religion is made necessary by recent discussions of the very idea of religion (what makes religion a universal category? How has monotheism - especially Christian monotheism - affected our ideas of what devotion is?). The anthropologist Ugo Fabietti has recently explored what he calls the 'materiality of religions'. His analysis investigates the common functions of objects, images, bodies and substances across faiths. ${ }^{4}$ Analogously, Alexei Lidov has reflected on sacred space, what he defines hierotopy, that is, the set of conditions that make possible contact with the transcendent (or what he defines, in Mircea Eliade's term, 'hierophany'). ${ }^{5}$ What are the conditions that make this contact possible within the household? Why do we feel the need to differentiate between domestic devotions and public performances of devotional practices? This volume addresses these fundamental questions from an ambitious transcultural perspective, moving away from a merely European dimension. We have chosen to embrace a global view which is intrinsically more inclusive from an intellectual point of view, while also allowing us to address a much wider range of questions in many fields of knowledge. It is an obvious intention and purpose of this volume to carry out a serious examination of those perspectives that attempt to penetrate the concept of 'religious devotion' in a 'domestic' setting within global history. Our sense of global history implies that we are interested in understanding human actions and reactions, rituals and behaviours in the religious devotional realm in the medium and long term. The presence and development of 'domesticated' rituals (i.e. practised in the tranquillity of one's home, to be understood here as the place where one lived, as we will see) that can be referred to under the name of 'devotions' within human communities across the world is the main subject of our inquiry. Global history, as a reality and not just a historiographical category, is something that implies recognizing universal human traits even in the practices of religion and ritual, at least at some levels, while, however, simultaneously negotiating and maintaining identities and social relationships

in Europe, for example, in disseminating new scientific ideas and in acting as a vehicle for religious propaganda. In fact, as the author argues, the invention and consequent dissemination of the printing press in both Europe and China may function as a key to the creation of legitimate parallelisms in the use of the term 'early modern', applied to both geographic areas in the sixteenth and seventeenth centuries, "Introduction" 1-18.

4 Fabietti U., Materia sacra. Corpi, oggetti, immagini, feticci nella pratica religiosa (Milan: 2014).

5 Lidov A., "Creating the Sacred Space: Hierotopy as a New Field of Cultural History", in Carnevali L. - Cremonesi C. (eds.), Spazi e percorsi sacri. I santuari, le vie, i corpi (Padua: 2014) $61-89$. 
at an individual and a collective level, thus ensuring the continuation of human and cultural diversity.

One of the advantages of a global perspective is that events, habits or phenomena that were once thought to be unique to a given area, and therefore disconnected from each other, turn out to be not just 'local' matters. Rather, they are, at least to an extent, a product of people and regions that are part of larger networks. In other words, 'things' occur locally, but are not determined necessarily or solely as a result of local influences or factors. On the other hand, local changes can effectively alter the nature of wider networks. In order to develop an improved appreciation for how religions have been connected in the past, we need to be able to better evaluate intensified connections among them in the light of devotional rituals forever present in human contexts, such as the necessity to advocate for the sacred. On the other hand, things are naturally more complicated and require a stronger theoretical effort than simply developing local histories and putting them in connection/ comparison with other local histories taking place somewhere else in the world. How should we proceed then? What and where should we emphasize? Are there recurring problems/processes/rituals/habits that permit generalization? Or is everything that has happened in a given place unlike anything that has happened elsewhere? It can be argued that there are deeply embedded patterns in the way humans approach the sacred, but at the same time one cannot deny the existence of mentalities and habits that present even greater differences than those that we can analyse here. From our point of view therefore, it is not crucial to argue that there is a strict separation between the European and extra-European modes and ways of religious and devotional activities, both analytically and historically, but rather that they inform one another theoretically and empirically. In this sense, the search for patterns or patterned processes of typical individual religious experiences of devotion in global history is part of the intellectual preparation needed for better understanding a 'global history of devotion'. This should be considered a set of processes not necessarily or not entirely separated from each other, although of course different one from another. The essays contained in this book illustrate instances of 'global histories of devotion' in the past: the study of these histories casts further light upon processes of cultural and religious parallelism, for they bear similarities that legitimately call for comparison. For these reasons, as we shall see below, we have chosen to combine a comparative and a connective approach.

Naturally, putting together experiences and narratives that are so different from each other raises a few questions. What are our aims or intentions in trying to link these disparate facts and circumstances closely together? For 
whom or for what is this type of research intended? Different authors dealing with different subjects in different areas and time periods take, obviously, different methodological and intellectual positions on these issues. One may argue that we seek to establish positive knowledge about facts, structures and outcomes of these case studies. In fact, this book is a sort of 'mapping exercise' through which a cumulative body of knowledge can be established. In this sense, a positive knowledge about the past is in itself valuable, as it is the attempt to comprehend the spiritual needs of people of the past, and how these needs intersected to shape people's daily devotions in areas as distant as those portrayed by the essays of this volume. The purpose of Domestic Devotions in the Early Modern World, therefore, is to illustrate the diverse and heterogeneous ways of practising one's devotion and to demonstrate how different methodological and intellectual approaches, if used in accordance with historical analysis, can help to reinterpret the past.

Important to our approach is the definition of religion in the way Richard Trexler imagined it, namely a 'system of reverential behaviour' rather than a community of beliefs as it has come to be understood in the post-Reformation world. 6 To make his case, Trexler had to define the word 'ritual'; he defined it as verbal and bodily actions that become relatively fixed in the contexts of specific spaces and times. Can the practice of religious devotion be regarded as also being a ritual? Yes, to a certain extent, as it too followed a pre-ordained path. Not always, however, would religious behaviour follow a rational path, nor a predictable one. The power of religious images, the gestures of piety, the spiritual cravings of the weak and displaced, and the rituals that embraced these manifestations of religion, all shaped the intimate, spiritual experience of the devotee. The individual and intimate emotions generated by these rituals cannot, as a consequence, be foreseen; they are often upheld by impulsive, or even volatile spiritual moods that are not subjected to social rule. Furthermore, what mattered the most to the people practising their devotions was not the religion of intellectuals, of theologians, and of the prelates of the Church or formalized institutions, but everyday religion, the miracle-working images, the street processions: no matter how governments and churches try to control them, populations will create their own religious reality in the public life of the streets and, all the more, in the intimacy of their homes.

It becomes clear that to write about rituals and people, and rituals and devotion implies therefore a certain confidence in telling stories. But if we write about religious experiences and devotions in the past - that we know were rather unprompted and unconstrained - we ought to consider the natural and

6 Trexler R.C., Religion in Social Context in Europe and America, 1200-1700 (Tempe, AR: 2002). 
free domestic environment within which these devotions would take place. Therefore, we cannot avoid addressing issues such as the 'home' (what do we call 'home' in a time span of more than 400 years and in a global context?), 'household' (is 'household' to be considered as synonym for 'home' or rather, for 'family'?), 'identity', and even the social space and social roles (within the urban context) where an individual's identity was usually fully explored and put into practice. If the place of every individual in society is shaped by the presence of these crucial factors combined together, and if these factors influence and ultimately shape the interaction of the individual with all socially expressed rituals, such as those performed in religious devotion, then, in the light of this narrative, we should seek to understand them better.

First of all, is the concept of 'domestic' something that can find its exhaustive explanation in the debate of 'private' versus 'public'? Did there exist a clearly defined and definable space that can be called 'private', in which intimate activities such as praying, or meditating, were to take place? If we look back to the medieval city, we realize that religion was in tune with the urban architecture and the urban layout: everything had to serve God, even civic architecture. Still in the fifteenth century cities testified to this pursuit of urban and 'religious' harmony through a design in which the collective spaces that hosted the ceremonies and festivities each year, through the exposure of sacred images for instance, contributed to renewing the collective representation of the city itself. The medieval city thus appeared as a place where individuals were not 'self-sufficient', but rather sort of captives of a specific social role. In this context privacy much depended on one's social status: the higher this was the more likely one was to enjoy some intimacy. This - in a society like that of the medieval city, made up predominantly of masses of poor and lower status people, and where it was the Church who exerted a strong control over public life - explains why collective spaces were prevalent, outside, as well as within houses. Conversely, the space of the Renaissance city was the product of a territoriality based primarily on concepts of reciprocity and redistribution, a world in which the market, civil life, and even religious sentiments and rituals were often subordinated to the political order, which exerted a strong influence over citizens but let them, to an extent, reappropriate their individual experiences and spaces. ${ }^{7}$

If one turns one's eyes further afield and to a later time period, to extraEuropean cities, for instance those in South America, one can see how until the end of the eighteenth century, with the founding of hundreds of these new cities, processes of evangelization were in act through the construction

7 Sack R.D., Human Territoriality: Its Theory and History (Cambridge, MA: 1986) 114-124. 
of ideal urban models based once again on religious order, where little was left as private: most of the city's spaces were in fact conceived as public. The city of the New World was thus, in essence, replicating a town which was halfway between a medieval and a Renaissance town where public space was always characterized by the presence of an imposing church (or cathedral); where social life and religious practices were largely carried out in missionary churches and 'colonial' houses, but dominated by public spaces, which were closed areas but opened on large patios, onto which the houses faced. ${ }^{8}$ In this context privacy was rarely achievable. It must not be forgotten that colonization meant primarily evangelization: attempts to build the ideal city were governed by the idea that the staunchest Catholic values must be represented. To effect these social programs, the authorities often employed the help of the Society of Jesus. From the end of the sixteenth century - in the forefront of the Counter-Reformation program - the Jesuits had the task of evangelizing the Spanish overseas territories (especially Mexico and Central and South America), but missions were also active in Japan, China, and the East Indies. ${ }^{9}$

If we turn to the Middle East and try to understand what lies behind the concept of 'privacy' there, we realize that there was a higher and stricter degree of division (and certainly less porosity) between environments considered 'private' and those deemed 'public'. Considerations of high respect for the privacy of subjects had their roots deep in the past, and with the advent of the Ottomans to power, the relationship between ruler and subjects was not altered: in this, Ottoman law differed radically from contemporary European law, which was more invasive with regard to privacy. A general division between public and private was commonly held and understood, also on the basis of socioeconomic factors, familial and intrafamilial relationships, residential and social status, life experiences and so on; all these factors came together to shape the way privacy was conceived in people's minds. For example, subjects knew that as long as they kept to their private area they were protected from the intervention of state agents even if they committed crimes (in fact, if a crime was committed, it was the neighbourhood who was invested with the task of handing the culprit to the Ottoman agents, not the latter, who

8 Mumford L., The City in History: Its Origins, Its Transformations, and Its Prospects (New York: 1961) 48-49.

9 Durán D., Historia de la Indias de Nueva España e islas de la Tierra Firme, ed. K.Á. Ma. Garibay, 2 vols. (Mexico City: 1967); Trexler R.C., Reliving Golgotha: The Passion Play of Iztapalapa (Cambridge, MA: 2003); Klein C.F., "The Aztec Sacrifice of Tezcatlipoca and Its Implications for Christ Crucified", in Arnade P. - Rocke M. (eds.), Power, Gender, and Ritual in Europe and America: Essays in Memory of Richard C. Trexler (Toronto: 2008) 273-297. 
could not enter the culprit's home). In fact, Ottoman authorities were expected to operate only and exclusively in a public context. ${ }^{10}$ Did the existence of these safely and carefully guarded havens, private spaces undisturbed by the authorities, also favour private devotions? Were the latter domestically expressed and carried out possibly more freely than elsewhere? Did this particular context of spatial arrangements effect, in quantity and quality, a substantial difference from those devotional rituals emerging in contemporary European and South American cities?

Finally, if we turn our attention to East Asia, things yet again were different. The emergence of a private sphere in a relatively late period - compared to the Middle Eastern and European contexts (sixteenth-nineteenth centuries) - is still a debated subject. Recently, a group of East Asian historians have begun to postulate the possibility that the arguments offered by Jürgen Habermas (who introduced the idea of the emergence of a 'public sphere' in Europe only in the eighteenth century) are undoubtedly also applicable to non-European contexts. ${ }^{11}$ Historians of old Korea maintain, for example, that before the early modern period (expressed on a European-centred periodization) Korea was a country characterized by a predominantly agricultural economy, inhabited by a society divided between peasants and aristocrats, where religious identity was dominant: here concepts such as 'privacy' and individuality were practically non-existent. ${ }^{12}$ Although the concept which Habermas expressed in The Structural Transformation of the Public Sphere, involving a clear distinction between public and private, ${ }^{13}$ has been heavily criticized by some prominent scholars, such as Dena Goodman and especially Katherine Lynch (who argued that in the late medieval and early modern age, there were no

10 See Ayalon Y., "Ottoman Urban Privacy in Light of Disaster Recovery", International Journal of Middle East Studies 43, 3 (2011) 513-528; see also Marcus A., "Privacy in Eighteenth-Century Aleppo: The Limits of Cultural Ideas", International Journal of Middle East Studies 18, 2 (1986) 165-183.

11 Habermas J., The Structural Transformation of the Public Sphere: An Inquiry into a Category of Bourgeois Society (Cambridge, MA: 1962); Rowe W.T., "The Public Sphere in Modern China”, Modern China 16 (1990) 309-329; Ryan M.P., “Gender and Public Access: Women's Politics in Nineteenth-Century America", in Calhoun C. (ed.), Habermas and the Public Sphere (Cambridge, MA: 1992) 259-288; Forment C.A., Democracy in Latin America, 1760-1900 (Chicago: 2003); Ikegami E., Bonds of Civility: Aesthetic Networks and the Political Origins of Japanese Culture (Cambridge: 2005).

12 Yi T-J., "The Socio-Economic Background of Neo-Confucianism in Korea of the Fifteenth and Sixteenth Centuries", Seoul Journal of Korean Studies 2 (1989) 39-63.

13 Habermas, The Structural Transformation of the Public Sphere passim. 
strictly distinct public and private areas, but that they were correlated and almost inseparable), ${ }^{14}$ Habermas's postulates have been adopted by a number of critics. These have followed in his steps in formulating the hypothesis of the emergence of a public sphere in China, ${ }^{15}$ pre-modern and Tokugawa Japan (1600-1868), ${ }^{16}$ and Chosôn Korea (1506-180o), roughly during the same period in which it emerged in Europe, arguing, at the same time, for the idea of a parallel existence of a private sphere, notable, for example, in the secondary and tertiary teaching institutions called 'Academies'.17

From this brief account of a worldwide distinction between private and public areas, it emerges clearly that the understanding of what we refer to as public and private may vary according to historical periods and places, and that what was commonly regarded as a private or semiprivate area in one given place might not have been considered as such in another one in a different time. It is also apparent that if these differences were not so important in the transition from the medieval to the Renaissance city in a European context, this was not the case with the advent of radical changes in the formation of the bourgeois city in the eighteenth and nineteenth centuries. Here, the representations, forms, functions and use of public spaces, and therefore, likewise of private spaces, also changed on account of profound alterations in the processes of accumulation, exchange and consumption of goods necessary to material life. Even more important to our consideration, therefore, becomes the distinction between public and private within a global dimension: in fact, this issue is crucial to our point of view, since public and private spaces, as social products, largely influenced and characterized individual and collective religious and devotional experiences and processes. If the first, the public spaces - like squares, streets, churches, mosques and synagogues - provided access and enjoyment that were in principle equal for everyone, private places such as homes, on the contrary, were defined by the right of the owners to regulate their access. How, then, was private space organized and used in a place like the city, which, essentially up to the advent of the industrial era, remained, with few exceptions, a place of public and shared spaces? How did

14 Goodman D., "Public Sphere and Private Life: Toward a Synthesis of Current Historiographical Approaches to the Old Regime", History and Theory $3^{1}$ (1992) 1-20; Lynch K.A., Individuals, Families, and Communities in Europe, 1200-1800: The Urban Foundations of Western Society (Cambridge: 2003).

15 Fewsmith J., "From Guild to Interest Group: The Transformation of Public and Private in Late Qing China", Comparative Studies in Society and History 25 (1983) 617-640.

16 Ikegami, Bonds of Civility passim.

17 Koo J.-W., "The Origins of the Public Sphere and Civil Society: Private Academies and Petitions in Korea, 1506-180o", Social Science History 31, 3 (2007) 381-409. 
change also affect the conditions of existence and usability of private spheres, according to different criteria and specific legislation that obviously differed too, from place to place? Despite the obvious importance of this crucial aspect of the discussion, if we take for granted the existence of a definite 'public' space opposed to the concept of 'private', we may run the risk of overlaying the concept of public space itself with certain urban features (such as urban layout and civic architecture) - which were in fact very diversified. In turn this may lead to the mistake of not considering the range of different type of people who inhabited them. Observing public space, which exists in all human settlements of any kind and magnitude, only as a container of social practices leads to the misstep of confusing it with the functions to which certain places are destined for.

It is therefore even more necessary to understand in relation to the definition of 'public' what the house, the embodiment par excellence of 'privacy', meant to all these people, and what a 'home' environment signified to them. The home was the site of birth and death, of sickness and health, of conjugal life and reproduction, of child rearing, of hardship and prosperity. Across boundaries of faith and geography devotions evolved that served the needs of the members of a household as they confronted the demands of everyday life. We must pinpoint the necessity of treating the house as 'constituted by contingent and shifting concatenations of people, spaces, and objects'. ${ }^{18}$ In order to shed light on early modern and modern house interiors in a global context, then, studying spatial arrangements as well as the materiality of the household and the house itself becomes essential. Furthermore, the identification of transitional social spaces is crucial to understanding concepts such as 'domestic' versus 'public', or 'private' versus 'collective'. Of course a general interest in practices in the micro-space of the house must include domestic work and leisure, consumption, sociability, genre, display, and childrearing in their connections with devotional practice. While the authors of the essays in this volume emphasize how the display of certain religious artefacts, religious paintings, and works of religious art became a true vehicle for the individual and at times typical expression of an otherwise socially patterned ritual like religion, they also illustrate how the transmission and reinforcement of certain cultural ideas and artistic models became part of renewed social rituals within which religion played a major role.

Homes included spaces devoted to work, living, display, and quasi-public sociability, each of which could be filled with specific everyday objects, but

18 Campbell E.J. - Miller S.R. - Consavari E.C. (eds.), The Early Modern Italian Domestic Interior 1400-170o: Objects, Spaces, Domesticities (Farnham: 2013) 9. 
also with devotional items. Moreover, the diffusion of certain objects within the house, like religious paintings, devotional images, relics and so on, which were specifically reserved for public or semi-public display, can be regarded as crucial evidence for the circulation of knowledge and new devotional attitudes within a shifting history of devotion. While this concept has already been widely explored by both economic and material culture historians, it is the 'domestic' and 'devotional' approach that is worthy of note here. Again, transformation over space and time is key. More precisely, can we detect a functional differentiation and reorganization of domestic settings into several specialized spaces devoted to practising one's devotions? How does this vary according to geographic areas and time periods? Are there more similarities than differences? And if so, are the similarities pronounced? And what was the role of those who lived in the house in the construction of devotional processes? It is obvious that the question of social differentiation in the domestic sphere also applies to the analysis of devotion.

In this regard, of course, we must take into consideration the concept of human identity. Identity must be here understood as based on two fundamental issues: the first concerns our genealogical inheritance; in essence we all share a common heritage from our remote ancestors, in spite of millennia of migration and the formation of different cultures, languages and so on. This implies that to write about 'differences' in the way devotions were performed on an intimate level in such disparate areas of the world may be, in the end, comparable to an exercise like writing about one common 'devotional' identity. The second aspect concerns our mutual sharing of a single, common natural environment, which, if regarded as the whole world itself, regardless of its geographical, political, ideological, and human-imposed boundaries, is again, our 'home'. In this respect, the concept of human devotion worldwide becomes a subject extremely worthy of attention and makes this book a worthy enterprise for it encompasses an analysis of the multiple ways in which humans around the world manifested their common identity through expressing their natural and inner feelings about their relationship with the sacred.

What has identity to do with the family? Are these two concepts interrelated? Regardless of his or her social and economic condition, place of birth and residence, race, gender and so on, an individual is always a member of a family. A family is here to be understood as a group of persons united by ties of marriage, blood, or adoption, constituting a single household and interacting with each other in their respective social positions, usually those of spouses, parents, children and siblings. The family group should be distinguished from a household, which may include boarders and domestic personnel, or even slaves sharing a common residence. Additionally, however, sometimes the 
family included not only the parents and their unmarried children living at home, but also children that had married, their spouses, and their offspring, and possibly elderly dependents as well; such an arrangement is called an extended family. This is not the place to discuss each and every implication of the concept of 'household' and 'family' in the given areas explored by the essays in this volume. However, a clear specification must be made about what the household and family respectively represented in terms of shared values and individual identity in a wide context. At its best, the family performed various valuable functions for its members. Perhaps most important of all, it provided emotional and psychological security, particularly through the warmth, love, and companionship that living together generated between spouses and in turn between them and their children. The family also provided a valuable social and political function by institutionalizing procreation and by providing guidelines for the regulation of sexual conduct. The family additionally provided such other socially beneficial functions as the rearing and socialization of children, along with such humanitarian activities as caring for its members when they were sick or disabled. Remaining on the social side, the family served to promote order and stability within society as a whole. Additionally, on the economic side, the family provided food, shelter, clothing, and physical security for its members, some of whom may have been too young or too old to provide for the basic necessities of life themselves. One school of sociological and historical studies dating from the 1970s, especially of Western families (but not restricted to them), tended to concentrate on the family's economic and instrumental aspects, including the transfer of property at marriage and through inheritance, rather than its ideological or experiential qualities. This version of Western kinship was overturned partly by feminist studies, which instead subjected relations within the household, the control of property, and the concept of privacy to a sustained, and very analytical scrutiny. The notion of the 'private', defined as the world of the family as a haven from the 'public' world of work and competitive economic relations emerged, then, as an ideological construct that was itself a suitable object of analysis. In this regard, the endeavour to explicate kinship as a symbolic system of meanings that carried over into other ideological spheres (such as religion) had a strong influence on subsequent studies. ${ }^{19}$ Many later accounts of kinship therefore, both in Western and in non-Western societies, have retained the core of the culturalist approach, while also paying close attention to local experiences and understandings of kinship and providing nuanced depictions of how people in

19 On this see Wheaton R., "Family and Kinship in Western Europe: The Problem of the Joint Family Household", The Journal of Interdisciplinary History 5, 4 (1975) 6o1-628. 
a given culture might have divergent understandings of kinship depending on their age, sex, ethnicity, personal experiences, or other attributes. ${ }^{20}$

The volume is organized into thematic sections, where some of the common questions that emerge across the chapters will be flagged up, thus highlighting some of the possible links between them. Having briefly outlined the implications of a much-needed differentiation in the understanding of concepts such as 'public', 'private', and the definition of 'household', something to which we may attach from now on the concept of 'domestic', the study of devotion within a domestic context becomes crucial for the investigation of how public rituals could be performed in a more intimate setting, by private individuals. ${ }^{21}$ Religious festivities, wedding celebrations, and in general all those activities traditionally associated with collective and public gatherings were re-enacted within the home, which as a consequence became a place for socialization, as is the case of early modern Jewish or Muslim homes.

The chapters included in the volume show how domestic devotion was affected by and responded to contingency. It seems legitimate to talk of the micro-politics of domestic devotion as a tool for shaping the social body and social identities. Far from being merely a matter of individual observance, domestic piety involved the family in the broad meaning of kinship whilst also engaging communities or networks of believers. The building or strengthening of social bonds is often pursued through religious identity. This emerges in Torsten Wollina's chapter on the use of devotional books in early modern Damascus. The chapter, addressing the frequently overlooked issue of domestic devotion in the pre-modern Muslim world, relies on the journal by Ahmad Ibn Tawq, also studied in Marion Katz's contribution. Wollina draws from his source a wealth of information on the circulation of devotional books. In particular, he calls our attention to the threats associated with their use. Books were in fact tools for instruction and for the transmission of knowledge and were thus never entirely domestic. Wollina explains how the distinction between sacred and profane space was not spatial, but rather was created by

20 Hartman M.S., The Household and the Making of History: A Subversive View of the Western Past (Cambridge: 2004).

21 Although 'private' and 'public', and the very notion of 'domestic', when referred to the early modern home, are rather problematic categories, as discussed above; see also Sarti R., Europe at Home: Family and Material Culture 1500-1800 (New Haven - London: 2002), especially chapter 1 . 
'the deliberate pronunciation of words'. Books were venerated not only for their content but also as authoritative objects; they were often circulated within a close kinship group, thus reinforcing the latter's identity. A book was a source of blessings that extended to present and future relatives. Books thus connected their owners to 'admirable figures from past generations', conferring the spiritual blessings with which they were endowed upon their present and future owners. As a consequence, the power of the book, and the issues of control related to the circulation of texts, connected in a privileged way the domestic space with the public space of libraries and schools, tightening kinship bonds.

The dichotomy between private and public devotional spaces was also present within the Jewish world. Dotan Arad explores the peculiar case of Jews living in the Ottoman Empire. The relative religious freedom enjoyed by Jews ended with the kingdom of Bayezid II (1447-1512) when newly issued rules forbade the building of new synagogues so that only those existing before the Muslim conquest were allowed. These regulations conflicted with the desire of immigrant groups to preserve their identity and their liturgical traditions. Jews ended up locating their synagogues not in public buildings, but rather in private homes. In Arad's words, synagogues became a 'framework for self-determination'. Unfortunately, locating synagogues in private homes eventually led to conflicts between the owner and the worshippers, thus weakening the community. Hosting synagogues in the houses of private individuals caused the concentration of power in the hands of a few rich people. Arad's case study is also intriguing in that it shows how forms of private devotion could interfere not only with the establishment or tightening of a kinship bond, but also with the general economy of a city, thus making an impact on the dynamics of power at many different levels.

The political dimension of domestic devotions also emerges from Martin Christ's contribution on Johan Leisentrit and his instructions for the sick and the dying. A Catholic priest and the dean and general commissioner for Upper and Lower Lusatia, Leisentrit published his ars moriendi under the title of Catholisch Pfarbuch in 1578. Leisentrit was the head of the Catholic minority of Upper Lusatia, protected by the Catholic Habsburgs. In order to avoid conflicts with the Lutheran majority, Leisentrit thought it useful to accept some compromises and developments not entirely in line with postTridentine Catholicism. He was particularly concerned about the moment of death, when, given the state of despair and confusion, conversions could happen more easily. He thus inserted some Lutheran elements into his ars morien$d i$. In the absence of a central religious authority, it was possible to express religiosity in individualistic ways. In his work Leisentrit shows acute awareness of the fact 'that the bedchamber of a dying person was a liminal space in 
multiple ways: between public and domestic, sacred and profane, inside and outside, life and death'. Besides, he knew well that a burial code was a public affair, and a confessional marker. Given his peculiar position - he was responsible for both the Catholic and the Lutheran population of the region - it was likely that he wanted to avoid conflicts. Despite this, he built into his work a narrative in which Catholics were persecuted by Lutherans. In order to smooth over the confessional divide, he sought a kind of compromise, so as to thwart attempts at conversion on the death bed, which was a disputed place. As Christ observes, this had an intriguing consequence: 'Leisentrit's accommodating approach, together with the porous boundaries between public and private, throws up the question of what, precisely, a confessional, domestic space was'.

The increasing attention to global or world history almost necessarily implies a study also of how, in a connected world, religious beliefs interacted and related to each other. As a matter of fact, this point was being made by early modern historians themselves: at the same time as the first histories of the world were being written, an interest in the proto-comparative study of religion and of devotional practices emerged. ${ }^{22}$ It is arguable that, while public worship is more markedly shaped by official religious institutions, domestic devotion is to a higher degree responsive to the encounters between different religious communities, ideas, and beliefs. In the early modern world, marked by confessional divide (often within the same country) and global connections, the study of domestic piety should also be set in a global perspective. This volume posits itself precisely at the intersection of the contemporary debate between connective and comparative history. As Caroline Douki and Philippe Minard have pointed out in their introduction to the monographic issue of the Revue d'histoire moderne et contemporaine entitled 'Histoire globale, histoires connectées: un changement d'échelle historiographique?, we live in a moment of historiographical instability marked by different approaches. ${ }^{23}$ However, as recent scholarship has also highlighted, there is

22 On world histories, see Subrahmanyam S., Aux origines de l'histoire globale (Paris: 2014); Marcocci G., Indios, cinesi, falsari. Le storie del mondo nel Rinascimento (Rome - Bari: 2016). On early modern comparative histories of religion see Ginzburg C., "Provincializing the World: Europeans, Indians, Jews (1704)”, Postcolonial Studies 14 (2011) 135-150.

23 “Globale", “connectée", "comparée", "croisée”, "transnationale": les oscillations [...] manifestent assez l'instabilité du moment historiographique', Douki C. - Minard P., "Introduction", Revue d'histoire moderne et contemporaine 54 (2007) 7-21: 17. 
no need to choose between the two approaches. If, according to Douki and Minard, in their work on the multiple interactions of the early modern world, 'l'histoire connectée retrouve [...] la fécondité des effets de décentrement qui font la force de la méthode comparative', Heinz-Gerhard Haupt and Jürgen Kocka have stated that 'comparative and entanglement history are being combined in new ways.' ${ }^{24}$ In articulating the complex relations between a global world and local realities, connected history can combine its approach with the methodology of microhistory, creating what have been defined 'jeux d'échelles', or the continuous shifting from the individual case study to its broader context and vice versa. ${ }^{25}$ This volume seeks precisely to explore a series of case studies (investigated often with the tools of microhistory) and to set them into a connective context - thus exploring the reciprocal influences of different spiritual systems. ${ }^{26}$

The above-mentioned connective approach can be best appreciated in examples of coexistence (for example, Jews and Muslims in the Ottoman Empire, or Catholics and Moriscos in Spain, Confucianism and Buddhism in Korea, or Catholics and Protestants in France). Such a viewpoint warns against a static conception of confessional beliefs and practices and instead points to the ever-changing and reactive nature of devotion and religious identity. The house is the place where the effects of religious coexistence can be best assessed. On the one hand, religious minorities were often not allowed to display their devotion in public. Even where and when a certain degree of religious toleration was granted, the home was the safest place to perform religious rituals. On the other hand, when religious tolerance was not granted, it was advisable for members of religious minorities to keep in the house a range of religious objects that testified to their adherence to the official religion. This eventually (and inevitably) influenced their practices and beliefs, as the chapter by Borja Franco Llopis and Francisco Javier Moreno Díaz del Campo shows. The authors explore the use of images by Spanish Moriscos after their forced conversion in 1492. They point out that the presence of Catholic images within the household

24 Douki - Minard, "Introduction" 20; Haupt H.G. - Kocka J., "Comparison and Beyond: Traditions, Scope, and Perspectives of Comparative History", in Haupt H.G. - Kocka J. (eds.), Comparative and Transnational History: Central European Approaches and New Perspectives (New York - Oxford: 2009) 1-30: 21.

25 Douki - Minard, "Introduction" 21; on this issue see also Ginzburg C., "Microstoria: due o tre cose che so di lei", in Ginzburg C., Il filo e le tracce. Vero falso finto (Milan: 2006) $241-269$.

26 The study of devotion allows us to assess from a privileged point of view the idea of cultural métissage as one of the main consequences of early modern globalization; this is investigated by Serge Gruzinski in his book L'histoire, pour quoi faire? (Paris: 2015). 
was crucial in avoiding inquisitorial accusations; although this should not prevent us from believing that many former Muslims actually embraced the new faith. Franco Llopis and Díaz del Campo show that simulation - or dissimulation - was a complex issue. It revolved around the status of images in Islamic art and problems such as idolatry and iconoclasm. In many cases, the hatred of images was simply a reaction against the imposition of Catholic faith. In other cases, Moriscos showed a certain degree of flexibility, embracing Catholic beliefs and worship practices that they considered acceptable. For instance, the Immaculate Conception was a favourite as Muslims, too, thought that the Virgin had been conceived without sin. Likewise, St Alexius, a saint who had left his family to travel to Rome to follow the word of God, became symbolic of the Morisco diaspora and of those who had left their homes to venerate their God. This study shows that the Morisco home was a 'hybrid space of private devotions', one in which the coexistence of Christian and Muslim images created a form of religious syncretism. ${ }^{27}$

Issues of coexistence are also to be found in Korea where, under the Chosŏn dynasty, Confucianism became the state religion, replacing Buddhism after eight centuries. Soyeon Kim analyses a painting from 1562 known as The Gathering of the Four Buddhas. After reconstructing the history of the devotion and the iconography of the Four Buddhas, Kim sets the painting into the context of the ambivalent coexistence of the two religions. A 'non-orthodox icon', the Four Buddhas are 'non-orthodox deities that had been celebrated by public worship', and as such, they were connected more to popular beliefs than to Buddhist orthodoxy. The painting was commissioned by prince Yi Chongnin 'for the well-being' of his grandfather, Kwŏn Ch'an. Buddhism still exerted a strong influence on domestic and private piety: it is no surprise then that, two years after the official Confucian funeral rites, a Buddhist private rite was performed for Kwŏn Ch'an which involved a painting displaying a popular Buddhist iconography. If the chapter by Borja Franco Llopis and Díaz del Campo demonstrated what we might call religious eclecticism, this chapter exemplifies how coexisting faiths could be mutually exclusive of each other. At the same time, it allows us to assess a different side of domestic devotion, namely, its deep connections with popular beliefs. This aspect is peculiar to domestic piety: since, as we have seen, the house is intimately connected with

27 When using the word 'syncretism' we are aware of its potential risks, as highlighted in Richard H.L., "Religious Syncretism as a Syncretistic Concept: The Inadequacy of the 'World Religions' Paradigm in Cross-Cultural Encounter", International Journal of Frontier Missiology 31, 4 (2014) 209-215. 
humanity's deepest, ancestral concerns, anxieties and hopes, it is no wonder that domestic piety is affected by beliefs deeply rooted in folkloric culture. ${ }^{28}$

Kathleen Ashley, in her chapter on Protestant worship in France, adds further dimensions to the coexistence of beliefs in a time of religious change. She focuses on the case of Etienne Mathieu, a citizen of Chalon-sur-Saône, who was tried by the city authorities in 1594, at a time when Protestant practices were allowed, albeit with many restrictions, in France. The trial was triggered by his defence, during a public discussion, of everyone's right to practise his or her devotions within the private sphere. In fact, a man had been complaining about his neighbour singing the Psalms in the vernacular version in her house. This raised a complex jurisdictional problem. Huguenots used to sing the Psalms publicly in Marot's version to shape their identity as a group opposed to Catholics. In France, Protestantism was not entirely prohibited; rather, it was allowed under specific rules. But these were constantly changing, a situation that led to 'continuous contention over what behaviours were legal'. What is more, Etienne Mathieu had been a Protestant in the past: his shifting identities made him even more suspect and he was eventually sentenced to abjuration. This proves, as Ashley observes, that the domestic space 'was not off-limits' to regulation by the city authorities. Domestic devotion thus posed serious questions about the ways in which group as well as personal identities were shaped in the early modern world. At the same time, domestic devotion was a crucible for the elaboration of the increasingly complex relationship between civic and religious authorities as well as for the elaboration of the cultural and legal definition of the private sphere.

\section{3 Women and Devotion}

Our focus on the home invites us to pay further attention to female experiences of devotion, being, however, aware that their range of experiences did

28 We are very well aware of the problems connected with the use of terms such as 'popular religion' or 'popular culture' and of the ongoing debate about them; see Zardin D., "La 'religione popolare': interpretazioni storiografiche e ipotesi di ricerca", in Saccardo L. Zardin D. (eds.), Arte, religione e comunità nell'Italia rinascimentale e barocca (Milan: 2000) 3-23; Gentilcore D., "Was there a 'Popular Medicine' in Early Modern Europe?", Folklore 115 (2004) 151-166; Klaniczay G., "Popular Culture' in Medieval Hagiography and in Recent Historiography", in Golinelli P. (ed.), Agiografia e culture popolari. Hagiography and Popular Cultures (Bologna: 2012) 17-43; Benigno F., Parole nel tempo. Un lessico per pensare la storia (Rome: 2013) 79-114; Niccoli O., "Cultura popolare. Un relitto abbandonato?", Studi storici 4 (2015) 997-1010. 
not confine them to a home environment and to the role of dispensers or educators of religious/devotional habits. Although this book is not intended to figure within the wide panorama of publications on gender studies, the recognition of women as historical actors through their agency, craftsmanship, and religious sensitivity described in some of the essays cannot be underestimated. The analysis and the reach of some case studies prove that women's skill and overall ability to entertain successful social and business relationships for example, within a domestic context, does not necessarily make them ideal subjects for studying phenomena of religious devotion. Instead, women could promote themselves beyond a patriarchal equilibrium and find a place in society. Yet, we cannot but realize that some of our case studies empirically suggest the overwhelming link between the domestic and women's devotion. The study of women's religiosity in early modern Europe is well established as a vibrant field in its own right. ${ }^{29}$ This is less the case for Arab countries and even less so for East Asia. ${ }^{30}$ We believe that the recovery of this legacy of female religious experience helps to demonstrate conclusively that faith offered one of the most significant vehicles for the formation and expression of female subjectivity in the pre-modern and modern world.

The home proves an ideal place to study female agency and religiosity. In fact, houses were not only the main stage for important life-cycle events such as childbirth and death, but also the least restricted place where women could practice their religiosity. It is true that gender confounded religious ideals and practices or made them more problematic: in eighteenth-century Brazil, for instance, echoes of both Catholic ceremonies and material apparati of Catholic devotion persisted alongside syncretic devotional practices performed by female devotees, as Cristina Osswald's work makes clear.

This theme also bears upon the fundamental issues of the redefinition of domestic space and of the creation of sacred space. The existence, in different cultural settings, of domestic rituals, calls for a comparative outlook. In this regard, the materiality of devotion - in a broad sense - is key, both in the study

29 See some of the essays contained in Poska A.M. - Couchman J. - McIver K.A. (eds.), The Ashgate Research Companion to Women and Gender in Early Modern Europe (London New York: 2013), Part I: Religion.

30 On the subject of Islamic religious traditions and issues of essential concern to women, see Katz M.H., "Women's Mawlid Performances in Sanaa and the Construction of 'Popular Islam”, International Journal of Middle East Studies 40 (2008) 467-484; Katz M.H., "Scholarly Versus Women's Authority in the Islamic Law of Menstrual Purity", in KashaniSabet F. - Wenger B.S. (eds.), Gender in Judaism and Islam: Common Lives, Uncommon Heritage (New York - London: 2015) 73-105; on similar themes for Jewish religion and women's rituals and practices, see Biale R., Women and Jewish Law: The Essential Texts, Their History, and Their Relevance for Today (New York: 1995). 
of devotional artefacts and of domestic rituals. Hence, chapters in this volume pay attention to objects and to rituals such as, for example, those connected to food, and their role in demarcating sacred time and space (a subject explored in contributions that range in their focus from Muslim Syria to the Jewish world).

The definition of sacred space through rituals, practices, objects is thus at the heart of this volume. As many of the chapters suggest, the term 'domestic' seems to allude to a space of one's own, rather than specifically a house. It is thus fascinating to examine the process leading a former Tibetan princess to live like a Buddhist nun. Hildegard Diemberger offers us a rare glimpse into the life of one fifteenth-century Tibetan Princess, Chokyi Dronma (1422-1455), the daughter of a rural nobleman. The analysis focuses on the biography written by a male follower of the princess-nun, which is read comparatively alongside medieval European hagiographies. Diemberger demonstrates that domestic devotions were among the lay religious practices that offered a powerful framework within which a woman could deal with the full range of challenges that impacted on her life as daughter, wife, mother and grandmother; in fact in fifteenth-century Tibet the monastic life offered, through patronage, a way of promoting oneself in a male-driven universe, as well as a means to pursue one's aspirations if they involved any form of spiritual endeavour. Additionally, devotion performed in the home also meant interaction and negotiation between genders: women performing devotional practices often acted according to spiritual guidance provided by men, and men were frequently relied upon by women to 'create' multiple models of 'governance' of the household and family to support diverse spiritual goals. Although women were juridically located beyond the sacerdotal boundaries of the Church, gender studies have recently offered some of the most interesting paths into the religious world of women in the early modern and modern era, bringing into play women's religious experience per se, their relations with (clerical and lay) men, religious discipline, and the treatment of other marginalized groups.

Even stronger is the role of women in Jewish domestic devotions, as Debra Kaplan's chapter shows. Although the author suggests that the boundaries between private and public were not always clear-cut, it is true that there was a whole set of rituals and chores that were performed by women within the household. In fact, domestic work was infused to a great extent with religious meaning (we only need to think of highly ritualized acts such as the preparation of food); besides, Jewish women had no choice other than to marry. Particularly in crypto-Jewish communities, in which devotion was forcibly domestic, as Dotan Arad's chapter also makes clear, women became 'the leaders 
[...] who passed on traditions to the next generation'. The authors explore many of the domestic rituals and the ways in which a sacred space was created in the house, drawing interesting parallels with the Protestant 'holy household' studied by Lyndal Roper. As Kaplan suggests, Jewish devotion was thus highly gendered.

\section{$4 \quad$ Licit and Unorthodox}

Many of the chapters in the volume show how, both in Europe and in the wider early modern world, the household was the site of tensions between the laity and religious authorities, or of the interaction between licit and unorthodox practices. Religious hybridization, the survival of local beliefs, the existence of devotional practices that escaped the boundaries of official cultic forms were not peculiar to Europe but could be found all over the early modern world. It is no wonder, then, that religious authorities sought to tame (domestic) devotional practices that were perceived as inappropriate. These did not necessarily fall in the realm of heterodoxy: some belonged to traditions rooted in folkloric culture, or simply bore traces of pagan cultures. In such cases, the authorities tried to reformulate such practices in more orthodox terms. Yang Jungyoon explores the case of Dutch Calvinist authorities trying to reform and spiritualize the production of epithalamia. Nuptial texts were perceived as obscene, besides relying on the classical tradition of erotic poetry; furthermore, 'seventeenth-century vernacular epithalamia [...] played into a long tradition of the ancient custom of singing nuptial songs outside the bridal chamber'. Thus, they were re-written and replaced by biblical texts and images extolling the virtue of chastity. Alongside this, such ideas were disseminated in other genres, such as emblem books, conduct manuals and songbooks, all 'stressing the importance of religious rather than physical consummation'.

A case in point concerning the interaction between local and/or preexisting beliefs and orthodoxy is that of Brazil studied by Cristina Osswald. In 1720 Tridentine rules were finally applied to Brazil. The house became the centre of orthodox Catholic devotions (the cult of Christ and of Mary) and domestic rituals were strongly influenced by those of the major congregations, such as the Franciscans or the Benedictines, thus stressing the continuities between public and private worship. This was all the more evident in the case of the cloistered beatas, who lived a 'radical form' of religious life, often within the house. The peculiar social and economic structures of Brazil, organized in fazendas and engenhos, allowed for an even more marked overlapping of the boundaries between public and private. In fact, public ceremonies were 
celebrated in these rather isolated and small communities, thus becoming, in effect, private rites. The difficulty of exerting strict control over such a fragmented reality allowed 'an overly personalized view of worship' and forms of religious syncretism, which were also due to the presence of Indian and African communities. African slaves and Jews who had moved to Brazil after 1497, after Manuel I ordered the conversion of the Jews, kept on practising their rituals. Figures such as the pajés, a figure halfway between a priest and a doctor, continued to act, and old and new rituals were combined 'exaggerating the points of resemblance between the two'. Once again, it is evident how issues such as private and public, licit and illicit, were deeply entangled, and recurred, with only minor differences, across cultures.

\section{5} Shaping Identities

The benefits of a comparative approach may be seen by juxtaposing devotional practices, such as those from Damascus and Amsterdam: only by comparing and contrasting the experiences of different groups is it possible to discern what is structural and what is contingent about religious practices in the home. ${ }^{31}$

Alongside the use of religion to legitimize power and to promote social harmony, its role in fashioning identities and shaping communities has led to renewed interest in devotional themes. In this vein, Jews are not studied - as has been the case in the past - simply as financiers, moneylenders, Hebrew teachers, and victims of Christian anti-Semitism - though they were often that - but as members of communities which, though never free of the dilemma of negotiating

31 A successful model of comparative history was offered by Peter Burke, who, by analysing the cases of more than 200 Venetian aristocrats, and comparing them with members of Amsterdam city council, highlighted the inherent disparities between the two cities (religious denominations, different stances towards wealth and capitalism, urban layout and expansion), but also pointed to the similarities between them in terms of their civic pride, displayed by both Venice and Amsterdam, their essentially urban character, and their religious tolerance; see Venice and Amsterdam: A Study of Seventeenth-Century Élites (London: 1974). A second model is offered by the work of Adams J., The Familial State: Ruling Families and Merchant Capitalism in Early Modern Europe (Ithaca: 2007), who, by analysing the familial power structure of the Dutch elite and its companies (in particular the Dutch East India Company) in the Golden Age, created a convincing theory of how modern European states came to be shaped on the templates provided by the Dutch elite. Both studies promoted a successful example of how comparative historical analysis, starting from archival examination, coupled with careful investigation of causes and implications such as gender (Adam) and societal bonds (Burke), can function effectively. 
their relations with the dominant religion of the host country, possessed a dynamic culture of their own. The boundaries between Christianity, Judaism, and Islam are seen to be more fluid and porous. Current interest in globalization, mass migration, social inclusion/exclusion and materiality has repositioned our understanding of the modes of devotion in the early modern and modern period and deserves further attention.

The following chapters illuminate the need to expand our cultural horizons to imagine forms of devotion 'alternative' to the ones with which, as historians of European, or Western civilizations in general, we are probably more familiar, and also offer interesting interpretations of how religious devotion could act as a glue for collective identity, if not as a trigger for the search for a given identity.

Kathlyn Ryor, for instance, examines the importance of providing opportunities for literati artists to explore their cultural knowledge and identity through the medium of painting and relationships with other inspirational community members in late Ming Dynasty China. Assuming that each culture has one identity of its own, the literati artists in late Ming Dynasty China were the people who had created a 'second' identity through their artworks: the techniques employed by the artists were influenced by their religious ideas; and in turn these techniques were shaped by the artists' own domestic devotions. In essence, the artists were creating works in a world imbued with doctrinal and traditional depictions of Buddhist subject matter, reflecting with their ink brushes their beliefs and doctrinal affinities.

Igor Sosa Mayor reviews the practices involving relics enacted by lay people in seventeenth-century Spain, thus reminding us of the uses that were made of relics to help define a collective religious identity. The discussion converges upon the theme of the role of knowledge within the identification and validation of relics in the city of Arjona. Within knowledge transfer the process of validation of masses of relics was scrutinized and widely inspected, through the building of a collective identity. This chapter explores the function of knowledge within this almost professional search for relics and the validation of their identity. Its central argument is that users attached meaning and value to religious and sacred objects such as relics, going through complex social, religious and political processes where knowledge played a key role, and especially religious knowledge, for the latter negotiated and 'consumed' relics in different ways. The chapter argues that 'by means of experiments laypeople were able to prove or reject the possible sacred character of their objects, and at the same time, by doing so, believers were actively seeking experiences with the sacred at different levels - religious, sensorial and moral'. By conducting small experiments, laypeople took the initiative to investigate the qualities of 
the bones and ashes, and actively sought to challenge some of the positions adopted by the official church about the status of certain relics.

The main focus of the chapter by Marion Katz is again related to 'knowledge', a particular type of knowledge that is the evaluation of the complex of beliefs and practices around the commemoration of the Prophet's birth - the so called mawlid - in Syria, and precisely in Damascus, in the fifteenth century. According to Katz, the interchange between what was essentially a convivial activity, and the religious profile of the family of the house where the mawlid was held, helped to build a sense of identity and belonging among the individuals gathering for the celebration, a coherence thereby communicated to the wider community of devotees. Drawing on the diary of a fifteenth-century Damascene notary, who left a unique glimpse of these ceremonies by recording his daily activities for two decades starting in 1480, Katz explains that the interchange between the gathering of the people and the serving of food was appropriate 'to any landmark in a Muslim's life trajectory, and to any auspicious incident that might occur along the way'. The gathering activities, and the festive celebrations involving the preparation and consumption of food, have always been regarded by historians as a means of shaping a community identity and providing a framework for it. Thus, by integrating this approach into the religious aspect of the mawlid, we discover a new devotional relationship between the commemoration ceremony and a widespread feature of people's religious identity.

This section of the book examines devotional objects in different geographical, as well as confessional and chronological contexts. In fact, the book also comprises a series of contributions that focus specifically on the material aspects of modern devotion, exploring how each of the five human senses interacts with texts, holy imagery and many other items of devotion. By investigating the sense-object relationship/interaction from various perspectives, this section of the volume brings together the ideals of early modern and modern mystical beliefs, and the increasingly tangible material practice of piety. In fact, a recurrent theme of the past few years is that materiality is anything but static, much less dead. ${ }^{32}$ Conversely, according to a tradition that originated within medieval mysticism, materiality was something which went beyond the purely

32 A classic work that considers objects as having their own 'social life' is Appadurai A. (ed.), The Social Life of Things: Commodities in Cultural Perspective (New York: 1988). 
external, something that 'transcended' it, and that relied on the sensory world; ${ }^{33}$ thus mysticism enabled the devotee to see through the material things so as to recapture their real essence and inner qualities.

The interplay between the senses is also related to another theme that threads through this volume: the understanding of signs and symbols and of the meanings they conveyed to contemporaries. A simple sign could convey a wealth of meanings which were all interlaced and yet concentrated around the truth of God. For this reason a mere artefact or object could trigger and open the way for a whole series of reflections and thoughts. For instance, a simple image of Christ on the cross could initiate a long array of considerations and mental replications of his suffering.

The three contributions in this section address all of the themes discussed above, though in rather different ways. Accordingly, Suzanna Ivaničs chapter focuses on the understanding that amulets owned by Prague burghers could be used alongside Catholic items of devotion and Protestant bibles to allow access to the divine, and that the material of which amulets were made could itself act as a viable tool to interface with the transcendent. In her assessment of contemporary inventories and texts of natural philosophy and cosmology, Ivanič discusses the various forms of mediation between the 'magical'folkloristic and religious-devotional characteristics of the amulets examined, showing how the natural world - in a period of cross-confessionalism - was 'infused with divine power'.

The contribution by Hester Lees-Jeffries offers a close reading of John Donne's poem Devotions upon emergent occasions (1624), set in the context of other devotional texts and early modern material culture, and specifically, as the author suggests, on what might be called the 'early modern textile imaginary'. Lees-Jeffries explores Donne's poetic and devotional outpourings on death and other life-cycle moments, such as birth and the consummation of marriage, in relation to the 'shared textile contexts and experiences' of early modern people. In particular, she draws on Sasha Roberts' remarks about the 'ritual and symbolic significance' of the bed to suggest the ways in which the Incarnation and the Imitatio Christi, key themes in Donne's poetry, might be imagined and meditated upon in textile terms.

Hanneke Van Asperen discusses, likewise, the meditative significance of objects, specifically religious badges and images of pilgrims' souvenirs in devotional manuscripts, rejecting the idea that such instruments could not affect the way devotees perceived sacred images in their daily devotions. On

33 The book by Walker Bynum C., Christian Materiality (Brooklyn, NY: 2011) serves as an excellent example of this concept. 
the contrary, Van Asperen is at pains to demonstrate that religious badges were crucial to the development of the late medieval/early modern system of 'mental pilgrimage' because of the interplay with our human senses, imagination and memory, and the way human senses could produce a host of holy perceptions. In this respect, when people flicked through the pages of their devotional books and found badges marking some particularly noteworthy passages, the book became a shrine of knowledge, a 'physical container or prayers and religious pictures', bringing the devotee closer to the object of worship.

\section{7}

\section{Conclusion}

'Modern historians readily divide piety into public and private, but this neglects the crucial, fertile, common ground of the household' ${ }^{34}$ The meaningful point that was raised by Alec Ryrie is also at the basis of this book, which by adopting a multidisciplinary approach, encompassing global history, art history, history of material culture, history of literature and history of the book, social history and gender studies, is centred on the understanding that the home was of paramount importance to an individual's religious experience.

Temples and churches are the natural habitat of historians of religion. Institutions, public rituals and religious leaders have a way of commanding scholarly attention. And yet if we restrict our gaze to only the most conspicuous aspects of the past we miss much that is of fundamental significance to human life. This volume is premised on the assumption that the home was a central space of religious practice and experience throughout the early modern world. This seems to us to be an uncontroversial if hitherto underexplored claim, which is borne out by the rich and varied evidence presented in this volume.

The contributions to this book, which deal with themes dating from the fifteenth to the eighteenth century, tell of the intimate relationship between humans and the sacred within the walls of the home (the home is understood as the place where one lived, be it the cell of a monastery or one's personal domestic space). The devotional objects and the books explored here were part of a constant dialogue in everyday life. To reproductions of the sacred within the home adults directed their daily prayers in moments of discomfort or difficulty; to them children were taught to address their first prayers; to them children prayed at the invitation of their elders. Nearly everywhere, daily devotions were expressed in many habits of life, such as those related to life cycle

Ryrie A., Being Protestant in Reformation Britain (Oxford: 2013) 363. 
events (birth, marriage, death), as well as those connected to ways of dressing or eating, and therefore enmeshed within normal domestic life practices.

Starting from these methodological reflections, this book invites the reader to move beyond a concept of 'domestic devotion' that is clear cut and monolithic. Similarly, the volume also demonstrates that the home cannot be studied in isolation. The chapters instead point individually and collectively to the porosity of the home and its connectedness with other institutions and broader communities, and do so by adopting a flexible theory, one that can explain interactions taking place at different times, locations, cultural levels and so on. In this regard, we believe that the focus on domestic devotion from a comparative perspective is extremely fruitful.

Although the essays gathered in this volume cannot answer all the complex questions pertaining to domestic devotions and the multifarious relations between local cults and global history, they represent, however, a sampling of tentative but convincing suggestions about how and why we might go about unravelling devotional phenomena and constructing global history. This book is therefore dedicated to a new attempt to comprehend one of the most natural, common and shared human experiences - that is, devotion to the sacred, taking place in people's home environments across space and time - using historical enquiry to illuminate single processes of devotion. Many more studies will be needed to specify and explore further the historical processes of global devotional network construction and intensification. We have no doubt more will follow.

\section{Bibliography}

Adams J., The Familial State: Ruling Families and Merchant Capitalism in Early Modern Europe (Ithaca: 2007).

Appadurai A. (ed.), The Social Life of Things: Commodities in Cultural Perspective (New York: 1988).

Ayalon Y., "Ottoman Urban Privacy in Light of Disaster Recovery", InternationalJournal of Middle East Studies 43, 3 (2011) 513-528.

Benigno F., Parole nel tempo. Un lessico per pensare la storia (Rome: 2013) 79-114.

Biale R., Women and Jewish Law: The Essential Texts, Their History, and Their Relevance for Today (New York: 1995).

Burke P., Venice and Amsterdam: A Study of Seventeenth-Century Élites (London: 1974). Campbell E.J. - Miller S.R. - Consavari E.C. (eds.), The Early Modern Italian Domestic Interior 1400-1700: Objects, Spaces, Domesticities (Farnham: 2013). 
Chow K.-W., Publishing, Culture and Power in Early Modern China (Redwood City, CA: 2004).

Clunas C., Empire of Great Brightness: Visual and Material Culture of Ming China, 13681644 (London: 2008).

Clunas C., Superfluous Things: Material Culture and Social Status in Early Modern China (Cambridge: 1991).

Doran J. - Methuen C. - Walsham A. (eds.), Religion and the Household (Woodbridge, Suffolk - Rochester, NY: 2014).

Douki C. - Minard P., "Introduction", Revue d'histoire moderne et contemporaine 54 (2007) 7-21.

Durán D., Historia de la Indias de Nueva España e islas de la Tierra Firme, ed. K.Á. Ma. Garibay, 2 vols. (Mexico City: 1967).

Fabietti U., Materia sacra. Corpi, oggetti, immagini, feticci nella pratica religiosa (Milan: 2014).

Fewsmith J., "From Guild to Interest Group: The Transformation of Public and Private in Late Qing China", Comparative Studies in Society and History 25 (1983) 617-640.

Forment C.A., Democracy in Latin America, 1760-1900 (Chicago: 2003).

Forster M.R. - Kaplan B.J. (eds.), Piety and Family in Early Modern Europe: Essays in Honour of Steven Ozment (London: 2005).

Gentilcore D., "Was there a 'Popular Medicine' in Early Modern Europe?", Folklore 115 (2004) 151-166.

Ginzburg C., "Microstoria: due o tre cose che so di lei", in Ginzburg C., Il filo e le tracce. Vero falso finto (Milan: 2006) 241-269.

Ginzburg C., "Provincializing the World: Europeans, Indians, Jews (1704)", Postcolonial Studies 14 (2011) 135-150.

Goodman D., "Public Sphere and Private Life: Toward a Synthesis of Current Historiographical Approaches to the Old Regime", History and Theory 31 (1992) 1-20.

Gruzinski S., L'histoire, pour quoi faire? (Paris: 2015).

Habermas J., The Structural Transformation of the Public Sphere: An Inquiry into a Category of Bourgeois Society (Cambridge, MA: 1962).

Hartman M.S., The Household and the Making of History: A Subversive View of the Western Past (Cambridge: 2004).

Haupt H.G. - Kocka J., "Comparison and Beyond: Traditions, Scope, and Perspectives of Comparative History", in Haupt H.G. - Kocka J. (eds.), Comparative and Transnational History: Central European Approaches and New Perspectives (New York - Oxford: 2009) 1-30.

Ikegami E., Bonds of Civility: Aesthetic Networks and the Political Origins of Japanese Culture (Cambridge: 2005). 
Katz M.H., "Scholarly Versus Women's Authority in the Islamic Law of Menstrual Purity", in Kashani-Sabet F. - Wenger B.S. (eds.), Gender in Judaism and Islam: Common Lives, Uncommon Heritage (New York - London: 2015) 73-105.

Katz M.H., "Women's Mawlid Performances in Sanaa and the Construction of 'Popular Islam'”, International Journal of Middle East Studies 40 (2008) 467-484.

Klaniczay G., "'Popular Culture' in Medieval Hagiography and in Recent Historiography”, in Golinelli P. (ed.), Agiografia e culture popolari. Hagiography and Popular Cultures (Bologna: 2012) 17-43.

Klein C.F., "The Aztec Sacrifice of Tezcatlipoca and Its Implications for Christ Crucified", in Arnade P. - Rocke M. (eds.), Power, Gender, and Ritual in Europe and America: Essays in Memory of Richard C. Trexler (Toronto: 2008) 273-297.

Koo J.-W., "The Origins of the Public Sphere and Civil Society: Private Academies and Petitions in Korea, 1506-1800", Social Science History 31, 3 (2007) 381-409.

Lidov A., "Creating the Sacred Space: Hierotopy as a New Field of Cultural History", in Carnevali L. - Cremonesi C. (eds.), Spazi e percorsi sacri. I santuari, le vie, i corpi (Padua: 2014) 61-89.

Lynch K.A., Individuals, Families, and Communities in Europe, 1200-180o: The Urban Foundations of Western Society (Cambridge: 2003).

Marcocci G., Indios, cinesi, falsari. Le storie del mondo nel Rinascimento (Rome - Bari: 2016).

Marcus A., "Privacy in Eighteenth-Century Aleppo: The Limits of Cultural Ideas", International Journal of Middle East Studies 18, 2 (1986) 165-183.

Mumford L., The City in History: Its Origins, Its Transformations, and Its Prospects (New York: 1961).

Niccoli O., "Cultura popolare. Un relitto abbandonato?", Studi storici 4 (2015) 997-1010. Poska A.M. - Couchman J. - McIver K.A. (eds.), The Ashgate Research Companion to Women and Gender in Early Modern Europe (London - New York: 2013).

Richard H.L., "Religious Syncretism as a Syncretistic Concept: The Inadequacy of the 'World Religions' Paradigm in Cross-Cultural Encounter", International Journal of Frontier Missiology 31, 4, (2014) 209-215.

Rowe W.T., "The Public Sphere in Modern China”, Modern China 16 (1990) 309-329.

Ryan M.P., “Gender and Public Access: Women's Politics in Nineteenth-Century America", in Calhoun C. (ed.), Habermas and the Public Sphere (Cambridge, MA: 1992) 259-288.

Ryrie A., Being Protestant in Reformation Britain (Oxford: 2013).

Sack R.D., Human Territoriality: Its Theory and History (Cambridge, MA: 1986).

Sarti R., Europe at Home: Family and Material Culture 1500-180o (New Haven - London: 2002).

Subrahmanyam S., Aux origines de l'histoire globale (Paris: 2014). 
Trexler R.C., Public Life in Renaissance Florence (Ithaca, NY: 1991).

Trexler R.C., Religion in Social Context in Europe and America, 1200-1700 (Tempe, AR: 2002).

Trexler R.C., Reliving Golgotha: The Passion Play of Iztapalapa (Cambridge, MA: 2003).

Walker Bynum C., Christian Materiality (Brooklyn, NY: 2011).

Wheaton R., "Family and Kinship in Western Europe: The Problem of the Joint Family Household", The Journal of Interdisciplinary History 5, 4 (1975) 601-628.

Yi T-J., "The Socio-Economic Background of Neo-Confucianism in Korea of the Fifteenth and Sixteenth Centuries", Seoul Journal of Korean Studies 2 (1989) 39-63.

Zardin D., "La 'religione popolare': interpretazioni storiografiche e ipotesi di ricerca", in Saccardo L. - Zardin D. (eds.), Arte, religione e comunità nell'Italia rinascimentale e barocca (Milan: 2000) 3-23. 